\title{
Urban malaria transmission in Buenaventura, Colombia: entomologic aspects ${ }^{1}$
}

\author{
Víctor Olano, ${ }^{2}$ Gabriel Carrasquilla, ${ }^{3}$ and Fabián Méndez ${ }^{4}$
}

\begin{abstract}
In recent years, the number of cases of urban malaria in Buenaventura, Colombia, has increased, rising from 576 in 1987 to 3296 in 1991 and 2017 in 1992. For this reason, an epidemiologic study to identify malaria transmission patterns was carried out in this municipality on Colombia's Pacific coast. This article describes the entomologic findings regarding the vectors, their breeding sites, and the behavior of Anopheles species during the period from June 1993 to May 1994. Of the 469 potential breeding sites identified in the urban area, 28 were positive for anophelines, while in neighboring zones 20 out of 80 potential breeding sites were positive for the immature forms of these mosquitoes. Mining excavations, lakes, and commercial fish and crayfish rearing ponds were the places where A. albimanus was most frequently found. For A. nuñeztovari, the breeding sites were rain puddles and aquiculture ponds. A. neivai larvae were collected from bromeliads. Mosquitoes were collected both inside and outside houses, and 90\% of the collected mosquitoes were identified as A. albimanus. Of the female A. albimanus, $54.8 \%$ were parous. This species was found to have peak peridomiciliary activity between 6 p.m. and 10 p.m. The highest biting rate outside houses was 7.1 bites per person-hour and was observed during March. It is hoped that this entomologic information will permit the launching of a strong community participation process and the implementation of control measures that are guided by these results.
\end{abstract}

Malaria is an endemic tropical disease that constitutes one of Colombia's major public health problems. Among the factors maintaining malaria's endemicity in large parts of the country are parasite resistance to antimalarial

\footnotetext{
A Spanish version of this article has previously been published in this journal (Vol. 1, No. 4, 1997, pp. 287-294) under the title "Transmisión de la malaria urbana en Buenaventura, Colombia: aspectos entomológicos."

2 National Institute of Health, Santafé de Bogotá, Colombia.

3 University of Valle, Department of Microbiology, Cali, Colombia. Mailing address: Carrera 5a. \#6-05, Cali, Colombia. Fax: 57-2-883-4706.

4 Valle Departmental Secretariat of Health, Cali,
} Colombia. drugs; migration of nonimmune populations into malarious areas; socioeconomic and cultural conditions of the settlers, such as the type of dwelling used; resistance to antimalaria campaigns; prevailing disease control policies, strategies, and resources; public order problems; and vector resistance to insecticides (1). Another factor that has contributed strongly to maintaining this disease in our setting is lack of knowledge of the biological behavior of the different species of Anopheles involved. This knowledge is needed to accurately assess disease transmission patterns within each specific zone, so as to be able to implement anopheline control measures. Some studies have been conducted on this subject in Colombia (2-6), but more entomologic and epidemiologic research is needed.

According to Colombia's Malaria Eradication Service (Servicio de Erradicación de Malaria-SEM), 41 anopheline species have been recorded in Colombia (7). Selecting from these species, this article examines the three principal vectors-Anopheles (Nyssorhynchus) albimanus, Anopheles (Nyssorhynchus) darlingi, and Anopheles (Nyssorhynchus) nuñeztovari-and four secondary vectors-Anopheles (Anopheles) punctimacula, Anopheles (Nyssorhynchus) pseudopunctipennis, Anopheles (Kerteszia) 
lepidotus, and Anopheles (Kerteszia) neivai (2).

On the Pacific coast, 21 anopheline species have been identified $(2,8-10)$, of which the following have been recorded in the municipal seat of Buenaventura: $A$. (N.) albimanus, $A$. (A.) punctimacula, and $A$. (K.) neivai $(11,12)$. Of these, A. (N.) albimanus is considered the primary vector along the coast $(3,13,14)$. Another species of the region that transmits malaria is $A$. (N.) nuñeztovari $(4,10,15)$. In this vein, a report by Cristóbal Viveros (SEM, internal document; March 1993) on an entomologic evaluation carried out at 26 localities within the municipality of Buenaventura in the period 1987-1991 states that the species A. albimanus, $A$. neivai, and $A$. nuñeztovari were the ones maintaining active malaria transmission in the study areas.

In the recent past Buenaventura, the Colombian city with the largest port on the Pacific coast, recorded high numbers of malaria cases: 576 in 1987, 3296 in 1991, and 2017 in 1992 (16). For this reason, a project was launched to implement the primary care malaria control strategy in the urban area of Buenaventura. The strategy included case diagnosis and comprehensive care, taking into account the entomologic and epidemiologic aspects of the problem, the characteristics of the health services involved, and the population's knowledge, beliefs, and practices regarding malaria. The entomologic study reported here sought to identify the anopheline species acting as malaria vectors in the urban area of Buenaventura, and to delineate their relevant habits, biting rates, and types of breeding sites.

\section{MATERIALS AND METHODS}

Buenaventura, located an average of seven meters above sea level, has an average temperature of $28{ }^{\circ} \mathrm{C}$ and an average annual rainfall of $778.9 \mathrm{~cm}$. The city has a land area of $6078 \mathrm{~km}^{2}$ and is located $142 \mathrm{~km}$ from the city of Cali (17). The study reported here was conducted between June 1993 and May 1994 in the urban area of Bue- naventura and in the surrounding communities of Sitronella, Zacarías, Gamboa, La Jaci, La Gloria, and Variante Madroñal.

A comprehensive larval sweep was performed in Buenaventura and these surrounding areas to identify all potential natural and artificial anopheline breeding sites. The method used (recommended by WHO-18) entailed collecting 10 samples consisting of $250-\mathrm{cm}^{3}$ ladlefuls of water from every square meter of water surface being surveyed. After collecting and labeling the larvae, these were stored in glass vials with $70 \%$ alcohol.

Two cycles of larvae collection were conducted in the urban Buenaventura area-the first in June and July 1993 and the second in December 1993 and January 1994. In the "rural" neighboring areas, one cycle was carried out in August and September 1993 in the six aforementioned communities; then, in December 1993 and January 1994, another cycle was carried out in those communities where breeding sites had been identified.

All the entomologic data obtained were entered into forms designed for this study. The collected specimens were processed in the laboratory according to the method developed by Forattini (19) and were identified using the keys of Suárez et al. (20) and Cova García (21).

Anopheline collection with human bait is the method most often employed for sampling adult mosquito populations, since it permits assessment of man-vector contact as well as of biting habits, density, rate of sporozoite infection, and mosquito parity (22). In our case, sampling locations were selected in various neighborhoods, in both Buenaventura and the surrounding areas, based on the number of registered malaria cases and the existence of nearby breeding sites. Two collectors were employed, one inside and one outside of dwellings.

The WHO-recommended methodology was used for making these human bait collections (18). The collected mosquitoes were put into plastic containers and divided into lots according to the time of collection; they were then packaged, labeled, and transported to the laboratory for identification. The collections were made three times a week between 6 p.m. and midnight-except in October and November, when they were made between 6 p.m. and 6 a.m.

Also, a Shannon trap (23), using white light and a collector as bait, was operated between 6 p.m. and 10 p.m. for eight weeks; and a CDC light trap (obtained from the Centers for Disease Control and Prevention, Atlanta, Georgia) (24) was placed overnight (from 6 p.m. to 6 a.m.) at various sites to obtain samples of anopheline species present in the area. This latter trap was placed both inside and outside homes and close to breeding sites. The modified Mitchell trap (25), in which a calf was placed overnight (from 6 p.m. to 6 a.m.), was also used. The following day, the trapped mosquitoes were collected, packaged, and transported to the laboratory for identification.

In order to define the resting habits of anophelines (23), a search for these mosquitoes was carried out from 6 a.m. to 7 a.m. inside dwellings. To identify their natural resting sites, vegetation was inspected during the day.

Resting collections in animal shelters (23) were also made between 6 p.m. and 10 p.m., because of the significance of such collections for determining anopheline density, particularly that of $A$. albimanus. Although Buenaventura is not a livestockproducing region, a stable was found in the La Unión neighborhood of District (comuna) 12, relatively close to a site where adult mosquitoes had been collected with human bait. From July 1993 to April 1994 anophelines that were biting livestock at the stable or resting on stable walls were collected once a week.

In the laboratory, the collected and identified specimens were processed using an enzyme-linked immunosorbent assay (ELISA) to determine the extent of their infection with Plasmodium parasites. In addition, Detinova's technique (26) was used to dissect the ovaries of the $A$. albimanus collected with human bait for the purpose of determining their physiologic age. 
Descriptive statistical methods were used to assess the distribution of the most common species and breeding places. Tables and graphs were also prepared using the Harvard Graphics program (27). To determine the relationship between mosquito density during the rainy season and the frequency of malaria cases in the urban area, Pearson's correlation coefficient (28) and the Stata 3.1 program were employed (29).

\section{RESULTS}

\section{Breeding sites}

A total of 469 potential anopheline breeding sites were identified in the urban area of Buenaventura (Table 1), of which $28(6 \%)$ contained immature forms of these mosquitoes. Twenty-six (93\%) of the positive breeding sites were situated in Buenaventura's District 12, which also contained the greatest number of malaria cases. In the three "rural" areas where breeding sites were identified (Sitronella, Zacarías, and Gamboa), 20 of 80 suspected breeding sites were found to be positive (Figure 1). A. albimanus and A. nuñeztovari breeding sites were most frequently found in the areas of mining excavations, aquiculture ponds, and lagoons. A. neivai larvae were found in one of 27 bromiliads examined. Table 2 shows the general location and species identities of the 1483 anopheline larvae collected.

Of the two sweeps directed at finding breeding sites in the urban area of Buenaventura (see Materials and Methods section), the first (in June 1993) found 17 breeding sites with mosquito larvae, while the second (in January 1994) detected 11 additional sites (Figure 1). Only six breeding sites found to contain larvae when first sampled also had larvae when sampled in the course of the second sweep. In contrast, all 11 of the "rural" breeding sites found to contain larvae on the first sweep were also found to contain larvae on the second; in addition, nine more positive "rural" breeding sites were found on the second sweep.

\section{Adult mosquito collections}

Human bait collections. Eight anopheline species were collected with human bait (Table 2). A. albimanus was found to be the most common species in the urban area, while $A$. nuñeztovari was found to be the most common in the "rural" zones. The same pattern was observed with respect to distribution of immature forms.

Regarding the monthly density of adult mosquitoes, A. albimanus was found to have a biting rate outside dwellings in urban Buenaventura that varied from 0 bites per person-hour in August 1993 to 7.1 in March 1994 (Figure 2). More specifically, the highest $A$. albimanus biting rates were recorded outside dwellings in the months of October and November 1993 (a rate of 2.5 bites per personhour being recorded in October) and in the months of February, March, and April 1994 (the highest rate of 7.1 occurring in March). During the latter time period the biting rate for A. nuñeztovari, which like $A$. albimanus is exophagous, was 2.7 in the nearby rural area of Sitronella. This species' rate reached a peridomiciliary peak in July 1994 (see Figure 2). The remaining anopheline species had bite rates in urban Buenaventura that were lower than 0.6 bites per person-hour.

Figure 3 compares $A$. albimanus biting rates inside and outside dwellings at different hours of the day (from 6-7 p.m. to 11 p.m.-midnight). Like Figure 2 , it indicates greater biting activity outside dwellings. It also shows that the highest levels of daily biting activity tended to occur around dusk.

Figure 4 shows information used to examine possible correlations between mosquito density (as reflected in monthly biting rates for a year) and Buenaventura rainfall (as reported by the Colombian Institute of Water,

TABLE 1. The numbers of suspected anopheline breeding sites inspected and found positive in urban Buenaventura and neighboring communities, by type of site, in 1993 and 1994

\begin{tabular}{|c|c|c|c|c|c|c|c|c|c|c|}
\hline \multirow[b]{3}{*}{ Type of site } & \multicolumn{5}{|c|}{ Urban Buenaventura area } & \multicolumn{5}{|c|}{ Neighboring communities ${ }^{a}$} \\
\hline & \multicolumn{5}{|c|}{ No. of breeding sites } & \multicolumn{5}{|c|}{ No. of breeding sites } \\
\hline & Total & Positive & $\begin{array}{l}\text { Anopheles } \\
\text { albimanus }\end{array}$ & $\begin{array}{l}\text { Anopheles } \\
\text { nuñeztovari }\end{array}$ & $\begin{array}{c}\text { Both } \\
\text { species }^{b}\end{array}$ & Total & Positive & $\begin{array}{l}\text { Anopheles } \\
\text { albimanus }\end{array}$ & $\begin{array}{l}\text { Anopheles } \\
\text { nuñeztovari }\end{array}$ & $\begin{array}{c}\text { Both } \\
\text { species }^{b}\end{array}$ \\
\hline Excavations & 243 & 16 & 14 & 12 & 10 & 12 & 3 & - & 3 & - \\
\hline Fish ponds & 5 & 3 & 3 & 2 & 2 & 11 & 8 & 4 & 5 & 1 \\
\hline Ravines and streams & 35 & 2 & 2 & - & - & 10 & 1 & - & 1 & - \\
\hline Lagoons & 3 & 3 & 3 & 2 & 2 & 5 & 4 & 1 & 4 & 1 \\
\hline Bromeliads & 27 & $1^{c}$ & - & - & - & - & - & - & - & - \\
\hline Other (standing water, tires, etc.) & 156 & 3 & 3 & - & - & 42 & 4 & - & 4 & - \\
\hline Total & 469 & 28 & 25 & 16 & 14 & 80 & 20 & 5 & 17 & 2 \\
\hline
\end{tabular}




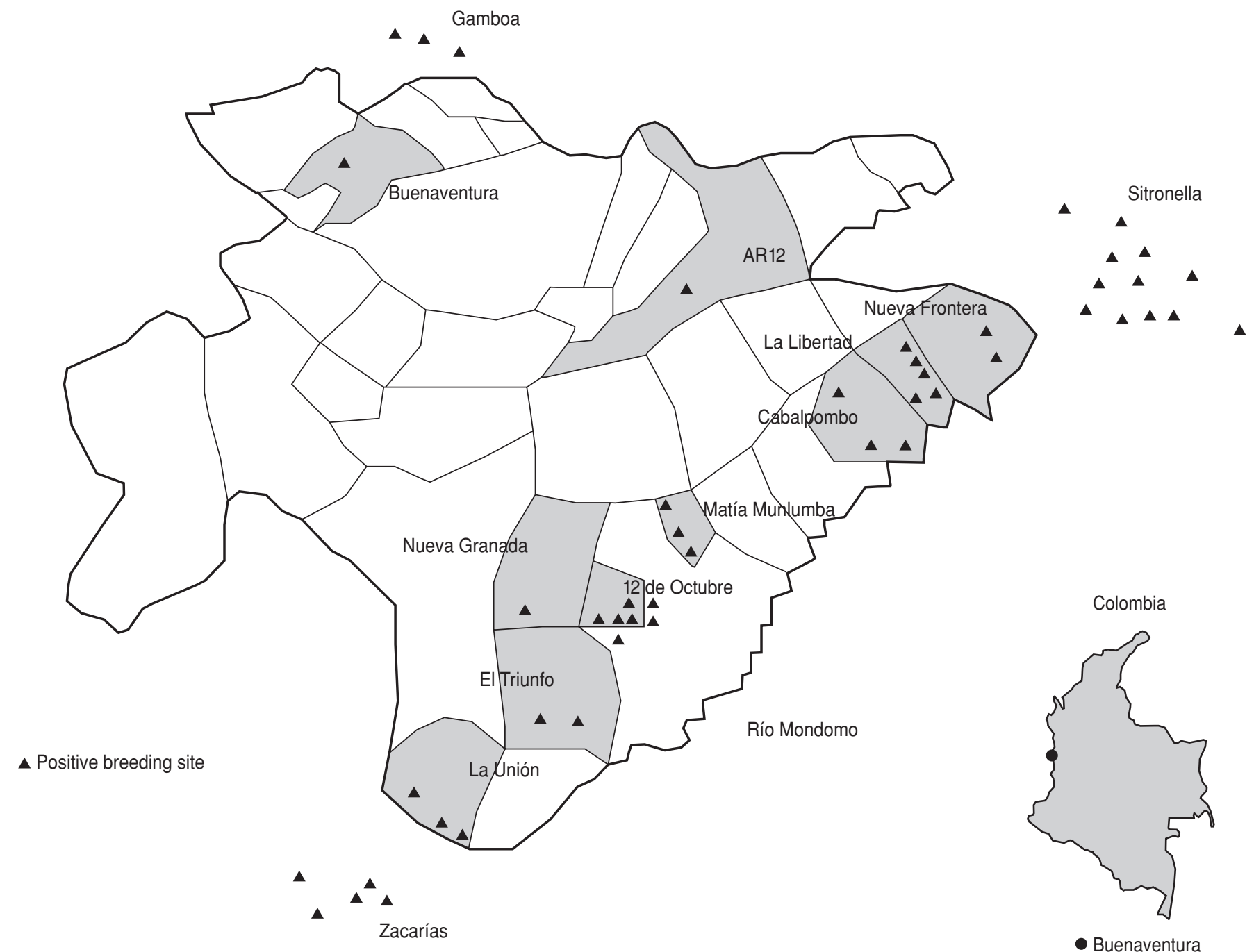

Meteorology, and Land Management-Instituto Colombiano de Hidrología, Meteorología y Adecuación de Tierras-personal communication, August 1994). No statistically significant correlation was found between rainfall in one month and the A. albimanus biting rate in the succeeding month when all the monthly June-May data were analyzed ( $r=-0.35$; 95\% CI: $-0.80,0.36)$. When only the June-December data were considered, a positive correlation was found ( $r=0.87,95 \%$ CI: $0.21,0.99$ ). However, following the same procedure for the January-May data yielded a negative correlation coefficient $(r=$ -0.68 ) that was not statistically significant (95\% CI: $-0.98,0.51)$. Despite this lack of correlation, as Figure 4 shows, the maximum biting rates (recorded in October 1993 and March 1994) were found to occur one and 3 months, respectively, after a sharp increase in local rainfall.

In Gamboa, one of the three nearby "rural" areas with anopheline-positive breeding sites, $90 \%$ of the 80 mosquitos caught were A. albimanus, as in urban Buenaventura (see Table 2). The apparent reason is that Gamboa itself is relatively urban, resembling a Buenaventura neighborhood more than a rural village. In Zacarías, however, a substantial portion of the adult anopheline collection consisted of $A$. neivai $(53 \%)$ and $A$. nuñeztovari (11\%), with
A. albimanus accounting for only $19 \%$. The high frequency of $A$. neivai, a forest-dwelling species (15), was apparently due to the abundance of bromeliads in Zacarías, the community farthest removed from the urban portion of Buenaventura and the one with the most rural character.

Mosquito trapping. No adult anophelines were caught in the light traps set out in Buenaventura during June and July 1993. However, the Shannon trap did capture anophelines (nine specimens of $A$. albimanus and two of A. neivai) in June-August 1993. In addition, the Mitchell trap cap- 
TABLE 2. Adult and immature forms of anophelines captured in urban Buenaventura and neighboring communities, by species

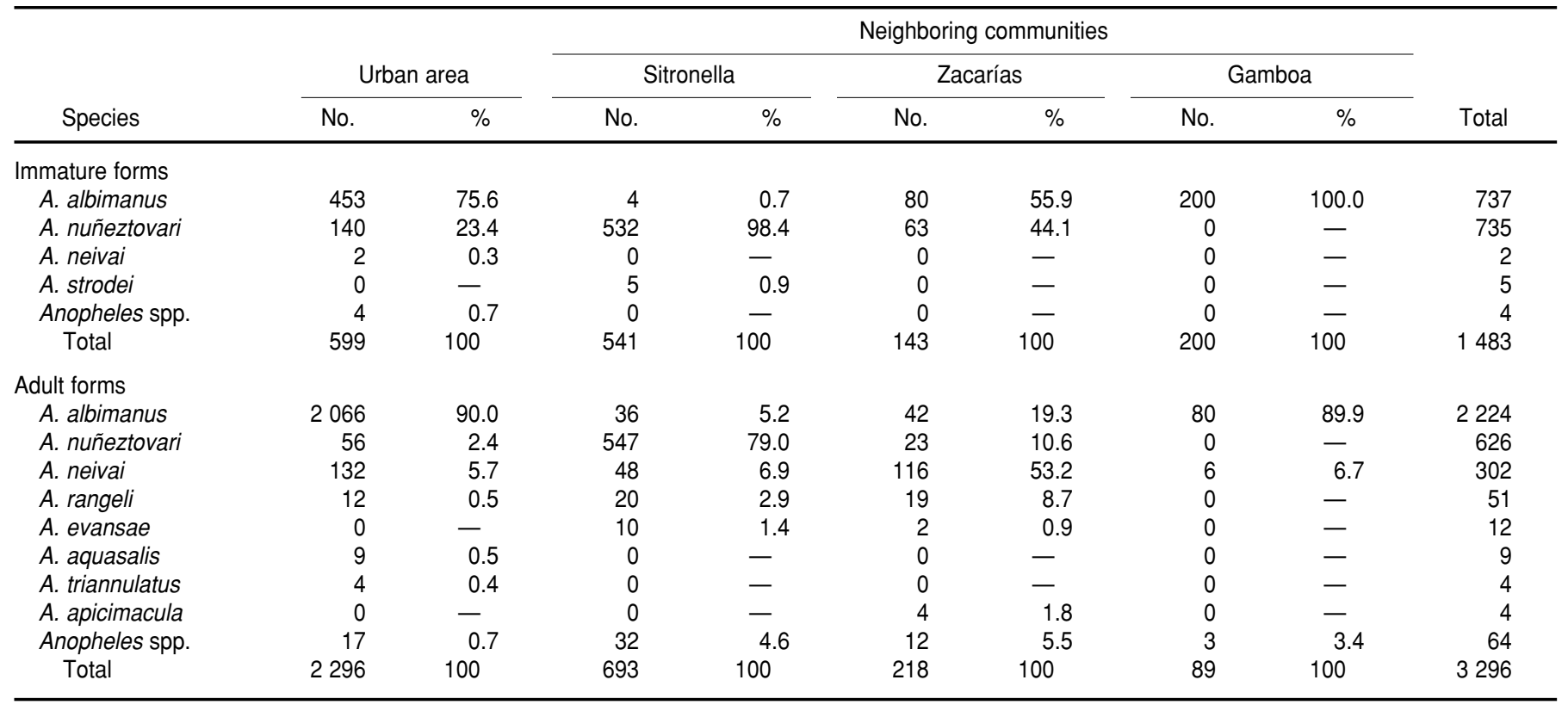

tured five specimens of $A$. neivai in November-December 1993.

Indoor and outdoor resting collections. Thirty-six hours spent attempting to collect resting mosquitoes in October 1993 did not succeed in capturing any anophelines inside houses, in natural shelters, or in stables. However, animal shelter collection efforts succeeded in capturing A. albimanus (137 specimens), A. neivai (two specimens), and $A$. nuñeztovari

FIGURE 2. Monthly biting activity found through human bait collections inside and outside dwellings for Anopheles albimanus in urban Buenaventura (left) and for Anopheles nuñeztovari in the neighboring community of Sitronella (right)

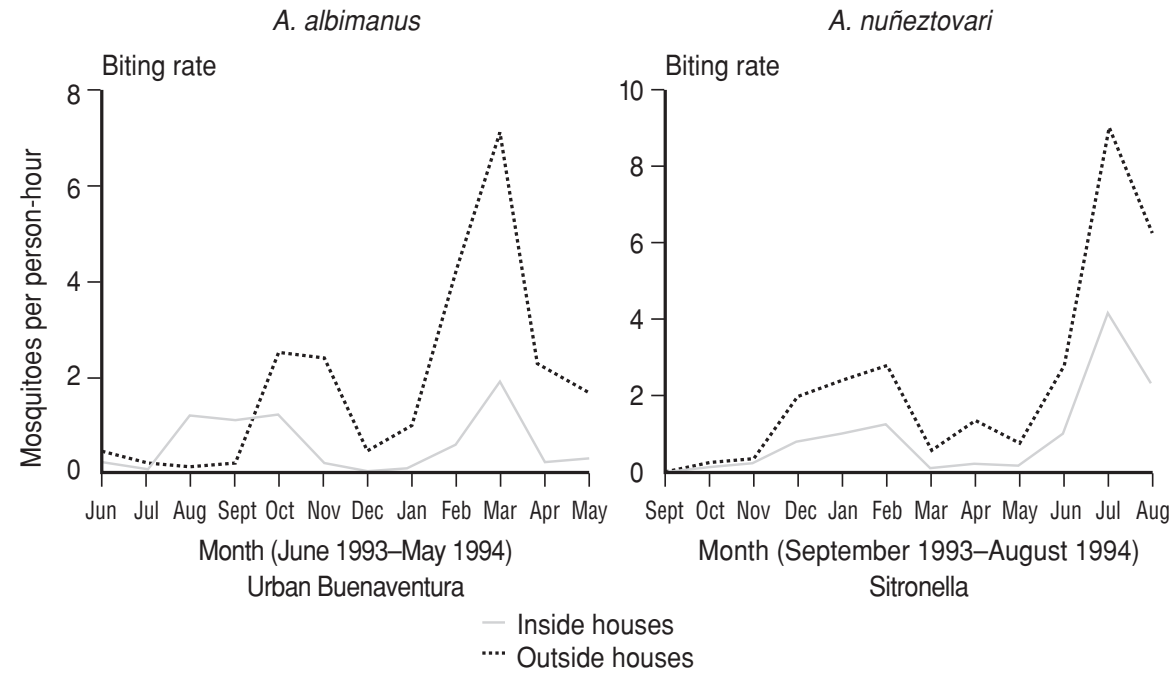

Malaria cases and biting rates. During the observation period, no statistically significant correlation was found between the malaria cases occurring in a given month and the biting rate recorded the preceding month ( $r=-0.36$; 95\% CI: $-0.79,0.31)$ (Figure 5).

\section{DISCUSSION}

As Quiñones et al. (5) have previously observed in other Pacific coastal areas of Colombia, our study found A. albimanus in a wide variety of 
FIGURE 3. Daily biting activity found for Anopheles albimanus between 6 p.m. and midnight in urban Buenaventura

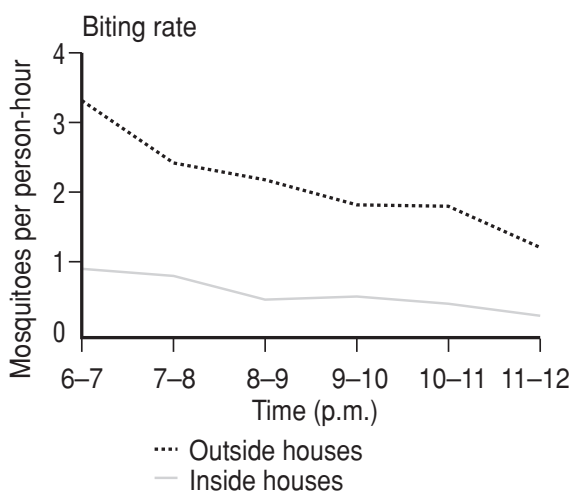

breeding places-including excavations, aquiculture ponds, lagoons, and puddles of standing rainwater. Another noteworthy finding was the presence of $A$. neivai in bromeliads, its usual breeding habitat. Other authors (4) have previously reported similar findings from the municipality of Charambira, Chocó, Colombia, where A. neivai was found in bromeliads and was reported as a local malaria vector.

Potential anopheline breeding sites were also identified in six communities neighboring Buenaventura, but mosquitoes were only detected in Sitronella, Zacarías, and Gamboa. Standing rainwater and ponds for raising fish and/or crayfish provided the potential breeding sites where A. nuñeztovari larvae were most often detected, and these ponds were the sites that contained the greatest larval density per square meter of surface area. Similar results have been reported from other malarious areas (30), where ponds designed to raise fish commercially have been found to serve as active breeding sites. These findings should be borne in mind by public health authorities when preparing control measures.

The fact that many of the active mosquito breeding sites found ap-
FIGURE 4. Fluctuations in Anopheles albimanus biting activity (intradomiciliary and peridomiciliary data combined) compared to monthly rainfall data for urban Buenaventura from June 1993 through May 1994

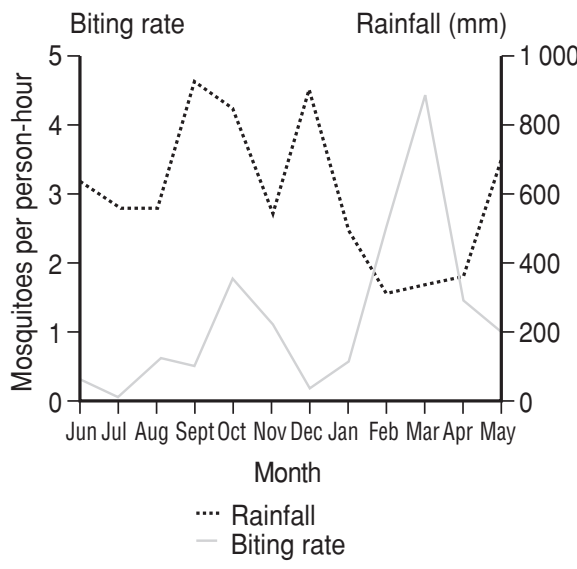

peared persistent indicates that a permanent entomologic surveillance system should be established under the control program to detect new mosquito breeding sites. It is also necessary to plan interventions with active community participation, keeping in mind the breeding sites' relevant features.

We found that the biting rates of $A$. albimanus increased after peak rainfall, a finding similar to those of other researchers cited by Frederickson (22). In Buenaventura, this species had an exophagous tendency, which also corresponds to results reported in other published studies $(5,31)$. The only apparent exception to this exophagous pattern in our study came in August and September, when there was little outside biting and relatively high biting rates inside dwellings. This unusual pattern was probably due to heavy rainfall during some of the collection days in August, as well as noncompletion of planned nocturnal collection activities in September.

Regarding peak periods of daily biting activity (see Figure 3), we found that peak peridomiciliary activity occurred between 6 p.m. and 9 p.m. and followed a downward trend until midnight. A similar pattern has been noted in El Salvador (32), and other re-
FIGURE 5. Fluctuations in Anopheles albimanus biting activity (intradomiciliary and peridomiciliary data combined) compared to monthly malaria cases recorded in urban Buenaventura from June 1993 through May 1994

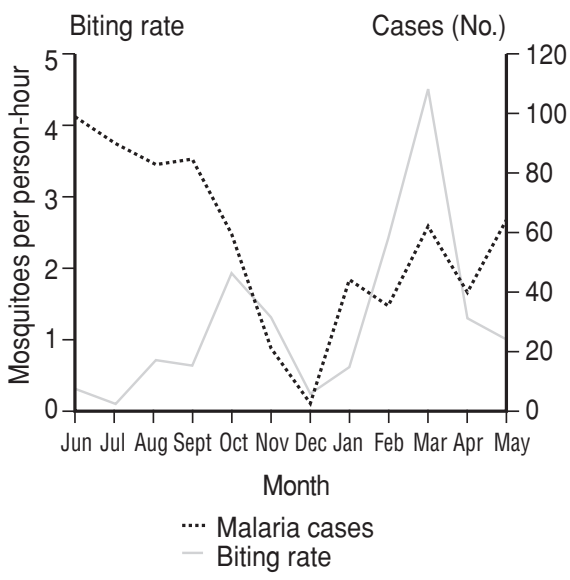

searchers have reported activity peaks before midnight in Central America and the Caribbean (22). In contrast to the results of this study, however, Quiñones et al. (5) reported a variable biting pattern in Colombia between 6 p.m. and 11 p.m., both inside and outside dwellings.

The aforementioned collecting of adult anophelines done in October and November 1993 took place between 6 p.m. and 6 a.m. inside dwellings (intradomiciliary collections) and at two times, from 6 p.m. to midnight and from 5 a.m. to 6 a.m., around dwellings (peridomiciliary collections), following the methodology suggested by Elliot (33). The intradomiciliary data indicated that a second peak of biting activity occurred between midnight and 1 a.m., a pattern noted elsewhere by other researchers (22). Between 5 a.m. and 6 a.m. there was again found to be more peridomiciliary than intradomiciliary biting activity, a finding similar to that of Rivera and López (34) in Nicaragua, who found $A$. albimanus to exhibit peak biting activity in this period. Overall, the results obtained lead to the conclusion that A. albimanus exhibits primarily exophagous behavior that is most intense in the first hours of 
the night, a point that needs to be considered when carrying out malaria prevention activities. Regarding the physiologic age of A. albimanus in the study area, our parity data indicate that a very young population is currently being subjected to pressure by insecticide spraying.

In Sitronella, $79 \%$ of the adult anopheline mosquitoes collected were A. nuñeztovari. This mosquito, considered the principal malaria vector in Colombia, is known to have either of two basic biting patterns. The first is typical of an exophagous zoophilic species that bites at dusk, while the second is characteristic of an intradomiciliary anthropophilic species that bites late at night. The latter pattern, which has been observed in northern Colombia and western Venezuela (35), is the one associated with transmission of the malaria parasite to man. However, Tadei and Correia in Manaus, Brazil (36), found that the A. nuñeztovari there exhibited both exophilic and anthropophilic tendencies, and that their biting activity reached its peak at sundown, primarily between 6 p.m. and 7 p.m. Similar results have also been reported from Suriname (37). Our findings in Buenaventura follow this latter pattern reported by Tadei and Correia, in which A. nuñeztovari exhibits mainly peridomiciliary biting habits together with peak biting activity early in the evening.
Resting collections in animal shelters, i.e. corrals or stables, indicated a relatively low density of $A$. albimanus in such shelters. These findings contrast with those in other areas where in only two hours (6 p.m. to 8 p.m.) over 1000 specimens of that species could be collected (V. Olano, unpublished data). The fact that beef cattle are not present in the study area makes the species have generally anthropophilic habits, and it is possible that this influences malaria transmission in Buenaventura. In addition, the fact that we did not find adult mosquitoes at rest in natural vegetation affirms the difficulty of using this technique as a sampling method. Other researchers have reported similar results (22).

No statistically significant correlation was found between the biting rate for a given month and the number of malaria cases in the urban area of Buenaventura. Other researchers (38) have pointed out that the increase in the number of mosquitoes after the rainy period may reduce the proportion of infected anophelines, which in turn could reduce the rate of malaria transmission.

In general, it should be noted that comprehensive vector control and entomologic surveillance activities include not only the destruction of breeding sites, but also physical and biologic vector control, dissemination of information, and education of the community. Within this context, the information gathered by this study on anophelines' hematophagous habits, biting rates, and vector behavior in the Buenaventura area has permitted design of a malaria control intervention in Buenaventura that has also taken into account the knowledge, attitudes, beliefs, and practices of the population, as well as the risk factors associated with malaria.

Acknowledgments. We wish to thank the WHO Special Programme for Research and Training in Tropical Diseases and the Foundation for Higher Education (Fundación para la Educación Superior-FES) of Cali, Colombia, for financing this project. We also extend our thanks to the National Institute of Health of Colombia; the Special Administrative Unit for Direct Campaigns (Unidad Administrativa Especial de Campañas Directas), especially the officials and technical staff of the Buenaventura headquarters; the Departmental Secretariat of Health of the Cauca Valley; and the Institute of Health of the Pacific (Instituto de Salud del Pacifico-INSALPA) for the technical and logistical support they provided during performance of the study. Finally, we are grateful to the people and municipal authorities of the 9th, 10th, 11th, and 12th districts of Buenaventura and those of the villages of Zacarías, Sitronella, and Gamboa for their support and collaboration.

\section{REFERENCES}

1. González G. Memorias Seminario Taller Malaria: descentalización y control. Medellín: Servicio Seccional de Salud de Antioquia; 1991.

2. Herrera S, Suárez MF, Sánchez GI. Uso de la técnica inmuno-radiométrica (IRMA) en Anopheles de Colombia para la identificación de esporozoitos de Plasmodium. Colomb Med 1987;18:2-6.

3. Quiñones ML, Suárez MF, Rodríguez A, Fleming G, Galvis LE. Comportamiento de Anopheles (Kerteszia) lepidotus Zavortink 1973 y su incriminación como posible vector de la malaria en el departamento del Tolima, Colombia. Biomedica 1984;4:5-13.

4. Carvajal H, Herrera MA de, Quintero J, Alzate A, Herrera S. Anopheles neivai: a vec- tor of malaria in the Pacific lowlands of Colombia. Trans R Soc Trop Med Hyg 1989;5: 609-612.

5. Quiñones ML, Suárez MF, Fleming GA. Distribución y bionomía de los anofelinos de la Costa Pacífica de Colombia. Colomb Med 1987;18:19-23.

6. Olano VA, Carrillo MP, Espinal CA. Estudios de infectividad de la especie Anopheles albimanus Wiedemann 1820 (Díptera: Culicidae) cepa Cartagena con plasmodios humanos. Biomedica 1985;5:5-10.

7. Súarez MF, Quiñones MS, Fleming GA. Revisión de algunos aspectos entomológicos de malaria en Colombia. Malaria Eradication Service (SEM); 1988. (Internal document).
8. Gast Galvis A. Biología y distribución geográfica de los anofelinos en Colombia. Rev Fac Med 1943;12:53-103.

9. Barreto P. Distribución de mosquitos Anopheles en el departamento del Valle del Cauca. Acta Med Valle 1971;2:45-48.

10. Fajardo P, Barreto P, Suárez MF. Anofelinos de Córdoba (Buenaventura). Colomb Med 1983;14:99-103.

11. Muñoz F. Anopheles (K.) neivai as a malaria vector in the municipality of Buenaventura [Education Sciences thesis]. Santafé de Bogotá: Escuela Normal Superior de Bogotá; 1974.

12. Colombia, Ministerio de Salud, Servicio de Erradicación de la Malaria. Vol II: Plan de Erra- 
dicación de la Malaria. Santafé de Bogotá: Ministerio de Salud; 1957.

13. Ferro C. Paludismo: problema de salud pública en Colombia. Rev Esc Nac Salud Publica (Medellín) 1974;1:41-45.

14. Suárez MF. Aspectos entomológicos del paludismo en Colombia. Bol Epidemiol Antioquia 1985;10:142-143.

15. Fajardo P, Alzate A. Anopheles nuñeztovari como vector de la malaria en el Bajo Calima, Buenaventura. Colomb Med 1987;18:14-18.

16. Méndez F, Carrasquilla G. Epidemiología de la malaria en el área urbana de Buenaventura: análisis de la ocurrencia en el período 1987-1993. Colomb Med 1995;26:77-85.

17. Instituto Geográfico Agustín Codazzi. Vol I: Diccionario geográfico de Colombia. Santafé de Bogotá: Editorial Andes; 1971.

18. World Health Organization. Vol I: Manual on practical entomology in Malaria. Geneva: WHO; 1975.

19. Forattini OP. Vol I: Entomología médica. São Paulo: Editora da Universidade de São Paulo; 1962.

20. Suárez MF, Quiñones ML, Robayo MA. Clave para la determinación taxonómica de larvas y adultos hembras de los principales anofelinos de Colombia. Santafé de Bogotá: Ministerio de Salud; 1988

21. Cova García P. Notas sobre los anofelinos de Venezuela y su identificación. 2a ed. Caracas: Grafos; 1961.

22. Frederickson EC. Bionomics and control of Anopheles albimanus. Washington, DC: Pan American Health Organization; 1993. (Technical paper 34).
23. Service MW. A critical review of procedures for sampling populations of adult mosquitos. Bull Entomol Res 1977;67:343-382.

24. Sudia WD, Chamberlain RW. Batteryoperated light trap: an improved model. Mosq News 1962;22:126-129.

25. Mekuria Y, Tidwell MA, Williams DC, Mandeville JD. Bionomic studies of the Anopheles mosquitoes of Dajabon, Dominican Republic. J Am Mosq Control Assoc 1990;6:651-657.

26. Detinova TS. Age grouping methods in Diptera of medical importance with special reference to some vectors of malaria. Geneva: World Health Organization; 1962. (Monograph series 47).

27. Software Publishing Corporation. Harvard Graphics 3.0 [computer program]. Mountain View, California: SPC; 1992.

28. Pagano M, Gauvreau K. Principles of biostatistics. Belmont, California: Duxbury Press; 1993.

29. Stata Corporation. Stata reference manual, release 3.1. 6th ed. College Station, Texas: SC; 1993.

30. López D, González R. Análisis de la dispersión y la abundancia de los estadios larvales de Anopheles nuñeztovari (gabaldón) en estanques piscícolas del municipio de Buenaventura. Colomb Bol Mus Entomol Univ Valle 1994;2:73-84.

31. Bown D, Rios J, del Angel Cabañas G, Guerrero J, Méndez J. Evaluation of chlorphoxim used against Anopheles albimanus on the south coast of Mexico: 1, results of indoor chlorphoxim applications and assessment of the methodology employed. Bull Pan Am Health Organ 1984;18:379-388.
32. Rachou R, Lyons G, Moura-Lima M, Kerr AJ Synoptic epidemiological studies of malaria in El Salvador. Am J Trop Med Hyg 1965; 14:2-62.

33. Elliot R. Studies on the man-vector contact in some malarious areas of Colombia. Bull World Health Organ 1968;38:239-253.

34. Rivera Mendoza P, López MM. Ecology and biology of Anopheles albimanus in a locality of the Pacific Coast of Nicaragua [abstract]. J Am Mosq Control Assoc 1991;7:635.

35. Fleming G. Biología y ecología de los vectores de la malaria en las Américas. Washington, DC: Organización Panamericana de la Salud; 1986. (PNSP/85-72).

36. Tadei PW, Correia JM. Biologia de anofelinos amazónicos: IV, Observações sobre a actividade de picar de Anopheles nuñeztovari (Diptera: Culicidae). Acta Amazon 1982;12: 71-74.

37. Panday RS. Anopheles nuñeztovari and malaria transmission in Surinam. Mosq News 1977;37:728-737.

38. Astaiza R, Murillo C, Fajardo P. Biología de Anopheles (Kerteszia) neivai HD\&K (Diptera: Culicidae) en la costa pacífica de Colombia. Rev Saude Publica 1988;22:101-108.

Manuscript received on 21 July 1995. Revised version accepted for publication on 20 March 1996.

RESUMEN En los últimos años, el número de casos de malaria urbana en Buenaventura, Colombia, ha aumentado de 576 en 1987 a 3296 en 1991 y 2017 en 1992, por lo que se desarrolló un estudio epidemiológico para identificar patrones de transmisión de la malaria en este municipio del litoral pacífico colombiano. Se describen los hallazgos entomológicos en relación con los vectores, los criaderos y el comportamiento de las especies de Anopheles durante el período comprendido entre junio de 1993 y mayo de 1994. De los 469 posibles criaderos del área urbana, 28 fueron positivos a anofelinos. En la zona rural vecina de Buenaventura, 20 de 80 posibles criaderos fueron positivos a las formas inmaduras del mosquito. Los sitios donde se encontró con más frecuencia Anopheles albimanus fueron las excavaciones de minería, los lagos y los estanques para piscicultura. Los criaderos de Anopheles nuñeztovari fueron los pozos de lluvia y estanques de peces. Anopheles neivai se recolectó en bromelias. De las capturas intra y peridomiciliarias de mosquitos adultos, $90 \%$ correspondieron a Anopheles albimanus. De las hembras, 54,8\% habían realizado al menos una ovipostura. Esta especie tuvo una actividad peridomiciliaria máxima entre las 18.00 y 22.00 horas. La mayor tasa de picadura peridomiciliaria fue de 7,1 picaduras por hora-persona y correspondió a marzo de 1994. Se espera que esta información entomológica permita poner en marcha un importante proceso de participación comunitaria e implementar medidas de control que estén orientadas por nuestros resultados. 